So far as concerns the assertion that leaving escaped fluids in the cavity makes the operator guilty of a patient's death, I append a significant sentence from Mr. Brown's recent lecture. He says: "With regard to simple fluid escaping from the cyst, unless it be of a purnlent or acrid nature, I do not lay great stress on getting it all out." Now, Mr. Brown has operated many times, his success has been great, and the value of his opinion is generally acknowledged. I cannot find it recorded that Dr. Savage ever succeeded in completing ovariotomy.

It is related that a certain somewhat pretentious professor, who had never seen a battle, once undertook to lecture before Hannibal on the art of war. I think his name was Formio, but do not doubt that the majority of your readers will recol. lect the story, and what Hannibal said when his opinion was asked about it. I remain, Sir, your obedient servant, Henry G. Wriget, M.D., M.R.C.P.

Somerset-street, Portman-square, Sept. 21st, 1864.

** Here this controversy must end.-ED. I.

\section{MAGISTERIAL CONSTRUCTION OF THE MEDICAL ACT.}

To the Editor of THE LANCET.

Sin,-On Tuesday the Marylebone Police Court was crowded with medical gentlemen anxiously awaiting (as they concluded) the certain conviction of an old offender for filching another man's name and professional title "cut and dried." This person, known by the name of Hamilton, and carrying on his avocation in Henrietta-street, Cavendish-square, whence he issues (in my name) those polite invitations "to ladies only," made his appearance in answer to a summons under the 40th Section of the Medical Act. To the surprise of all present, however, the pseudo Dr. Scott gets off "scot-free," with the Doctor in the bargain, the case being dismissed on the ground "that his assumption of that title did not imply that he practised as a physician," notwithstanding it was prefixed to a vile pamphlet "On Female Obstructions," \&c., and forms a prominent feature in those foul advertisements, published daily for the last few years in $m y$ name in certain penny papers, in defiance of repeated request to the contrary. However, it may be some satisfaction to know that, although the matter was thus dis. posed of for the present, a case was demanded and granted. So much for the sham Dr. Henry Scott.

Now let us see how it affects the real man, although I think the matter as deeply concerns the profession at large as myself. Can it be otherwise, Sir, than that the daily display of these productions in my name must do me serious professional injury, to say nothing of the continued annoyance of people addressing me on the subject? I could cite numerous instances to show that I have been taken, or rather mistaken, for this man. Scores of ignorant persons, and not a few evil minded ones, have set it down for certain, that $I$ am the author of these advertisements, or, at least, must have something to do with them otherwise the papers would not dare to insert them. That they have done so every man who "runs (or rides) and reads," will tell you ; and what influenre this has had upon my practice and prospects as a physician you may guess. The truth is well known that mine is a grievous case and a great hardship; in short, that $I \mathrm{am}$ a sad victim and a fine specimen of the shortcomings of the "Medical Act." What has it done for me? Registered me and taken my money. While the man whose name is not on the Register makes use of mine, christian and surname, together with my qualification. To show how well the thing succeeds, and that I am taken for the man in question, I may now mention a case or two in point :-

1. A letter from a solicitor in the City now lies before me, addressed to "Dr. Henry Scott," requesting the payment of three-quarters of a year's rent, due for some place I never saw. I need not add which Dr. this was for.

2. A patient came to consult me in a chronic case, for which they stated " that they should have seen me some nine months before had it not been for an unfortunate mistake". -namely, that a friend of theirs, upon hearing my name mentioned, took me for my advertising namesake. "What Dr. Scott?" was the query. "Dr. Henry Scott," was the reply. "The very man," replies their friend ; "don't go to him." Nor did they till nine months after, when some medical friend undertook to diagnose the difference between me and my double.

3. A gentleman called me in to attend his wife, who had a brother a surgeon. No sooner was the name mentioned than ap he jumps-"What Dr. Scott? Dr. Henry Scott:" This, the brother informed me, "settled the business." "Where does he live? Mind what you are about!" He went home, turned over the pages of the "Medical Directory," and then sent word " that I was not the felluw he took me for, but unfortunately the very man whose name was so shamefully made use of."

The common query of persons acquainted with the facts is, Does the law allow such a thing? Others wonder at the man's impudence, and amongst the élite of the profession, too, nothing daunted. No. We have heard of the age of stone, the age of bronze, and of the age of iron; but I think that when a fellow like this unblushingly makes use of another's name and qualification, and takes a house next door to the President of the College of Physicians to carry on the deception, we have arrived at the age of brass.

I am, Sir, your obedient servant,

Upper Woburn-place, Sept. 28th, 1864.

HENRY SCOT', M.D.

\section{POSITION OF SURGEONS IN THE ARMY.}

\section{To the Editor of The Lancet.}

SIR, - The following is extracted from the Court Journal of Sept. 3rd. Are these statements authentic ?

"A quarrel has been going on for some time past between the military authorities and the medical profession respecting the rank and position of surgeons in the army. A doctor of a certain number of years' standing is entitled, according to the regulations of the Horse Guards, to draw the pay and rations of a major. The doctor insisted that he should be not only paid as a major, but treated as one. The quarrel proceeded so far that young men would not for a time present themselves as surgeons, and matters were becoming serious. The Duke of Cambridge, however, remained firm; and it now appears that the surgeons have given way. At a late competitive examination more candidates presented themselves than there were vacancies to fill up, so that the quarrel may be considered to be at an end.

"Now that the usual relations are restored, Government may reform any grievances the doctors feel without the fear of having it said that they yielded to intimidation. For the sake of the army all classes will rejoice in the end of the struggle."

September, 1864.

$$
\text { I am, Sir, your obedient servant, }
$$

Percival Pott.

\section{THE PERSECUTION OF DR. GOSS. To the Editor of THE LANCET.}

SiR,- - Having taken much pains to ascertain the real facts of the case that has brought Dr. Goss into a dilemma, and which must, unexplained, bring him, for a time at least, under the censure of the public, permit me to say that a more unjust and iniquitous proceeding never took place before a Coroner's Court.

Here are two medical practitioners holding a fair position in the neighbourhood, Drs. Llewellyn and Gervis, attending jointly a M-s. Brazier, who lived fifteen days after delivery. I wish to direct your attention more particularly to this part of the story, which did not, of course, come out in evidence, the case having been stopped at trial. In a conversation which $D r$. Gervis had with Dr. Braxton Hicks referring to two cases of arm presentation which had occurred a week previously in the practice of each, Dr. Gervis said, "Oh, my case," referring to Mrs. Brazier, "is going on capitally, and is nearly, well." I speak this on authority. Yet, notwithstanding this comment, fifteen days after delivery and the above-mentioned conversation, we find Drs. Gervis and Llywellyn lending themselves to the excitement which the case had produced in the minds of the family of the deceased, and abstaining from giving the necessary certificate of the cause of death, thus throwing the matter into the hands of the Coroner's officer to deal with as against Dr. Goss, the former medical attendant, who had been by the bedside of the patient night and day. What further takes place? These two doctors, knowing there is an imputa. tion, and a most serious one too, hanging over the head of Dr. Goss, make a post-mortem jointly by order of the Coroner, never giving him the slightest warning or asking him to be present either by himself or his friends; and but for the courtesy of the Coroner, who told Cook, the officer, he thought Dr. Goss ought in fairness to be told of the inquiry, Dr. Goss would never have been informed at all-then not by regular summons but by a dirty slip of paper thrust into his hands, he not even knowing of the death of Mrs. Brazier. 